\title{
KONTRIBUSI PERBEDAAN PSIKOLOGIS PERAWAT TERHADAP PEMBERDAYAAN PSIKOLOGIS
}

\author{
Diah Arruum $^{1,2^{*}}$, Junaiti Sahar ${ }^{3}$, Dewi Gayatri ${ }^{3}$ \\ 1. Fakultas Keperawatan, Universitas Sumatera Utara, Medan 20155, Indonesia \\ 2. Program Studi Magister, Fakultas Ilmu Keperawatan, Universitas Indonesia, Depok 16424, Indonesia \\ 3. Fakultas Keperawatan, Universitas Indonesia, Depok 16424, Indonesia \\ *E-mail : arruum.diah@gmail.com
}

\begin{abstract}
Abstrak
Karakteristik perawat merupakan ciri-ciri perawat yang melekat terhadap dirinya, baik secara alami maupun yang didapat dari orang lain yang meliputi usia, jenis kelamin, tingkat pendidikan, status pernikahan, status pekerjaan, dan lama kerja. Karakteristik dapat membedakan psikologis perawat terhadap pemberdayaan psikologis dalam peningkatan kemampuan diri, motivasi intrinsik, dan kinerja perawat di rumah sakit. Penelitian ini bertujuan mengetahui karakteristik perawat dengan pemberdayaan psikologis. Desain penelitian yang digunakan deskripsi korelasi dengan cross sectional, sampel seratus lima belas perawat pelaksana. Hasil penelitian adalah jenis kelamin yang berhubungan dengan pemberdayaan psikologis perawat pelaksana $\mathrm{p}=0,041$, yang berarti terdapat hubungan antara jenis kelamin dan pemberdayaan psikologis perawat pelaksana (CI 95\% OR=1,001-66,893). Kemudian, 90\% perawat pelaksana yang berjenis kelamin laki-laki lebih berpeluang untuk diberdayakan secara psikologis, sedangkan perawat pelaksana dengan jenis kelamin perempuan yang berpeluang diberdayakan sebesar 52,4\%. Rekomendasi dari penelitian ini adalah perlu mengusulkan pendidikan formal dan pelatihan untuk perawat pelaksana khususnya yang memiliki lama kerja minimal lima tahun, serta perlu memberi pengarahan dari kepala ruangan untuk membina seluruh perawat melalui supervisi agar dapat memiliki kompetensi dalam melakukan tindakan di rumah sakit yang mencerminkan pemberdayaan psikologis perawat.
\end{abstract}

Kata kunci: perbedaan psikologis perawat, pemberdayaan psikologis

\begin{abstract}
Contribution of the Difference of Psychological Nurses's toward Psycological Empowerment. Characteristics of nurses are the traits attached to nurses, either naturaly or acquired from others. They include age, gender, educational level, marital status, employment status, and length of employment. The psychological characteristics distinguish nurses in psychological empowerment in improving self-efficacy, intrinsic motivation and performance of nurses in hospital. This research aims to know the characteristics and the psychological empowerment of nurses. The research design used cross-sectional correlation description with sample of 115 nurses. The results of the study are, gender that related with nurses' psychological empowerment $(p=0,041)$, which means that there is relation between gender with psychological empowerment of nurses (CI 95\% OR=1,001-66,893), and 90\% of male nurses are more likely to be empowered psychologically, whereas female nurses that is likely to be empowered is 52,4\%. Recommendations is the need to propose a formal education and training, especially for nurses who have at least 5 years length of work, as well as the need to give direction from head nurse to nurture all nurses through supervision in order to have the competences to carry out actions in hospital that reflect the nurses psychological empowerment.
\end{abstract}

Keywords: nurses psychological difference, psychological empowerment

\section{Pendahuluan}

Perawat sebagai individu yang bergerak di bidang kesehatan khususnya di rumah sakit harus mampu memberikan pelayanan keperawatan sesuai dengan keahlian. Pelayanan keperawatan yang diberikan harus menjamin asuhan keperawatan yang berkualitas (Aditama, 2008). Pelayanan yang berkualitas tersebut dapat dilakukan melalui pendekatan pemberdayaan, yaitu pendekatan 
hubungan dan pendekatan motivasi (Huber, 2006). Pendekatan hubungan bertujuan untuk memperbaiki kinerja, sedangkan pada pendekatan motivasi bertujuan untuk menciptakan tangggung jawab, kemampuan, komitmen, dan keterlibatan perawat (Huber, 2006).

Keterlibatan individu pada setiap pekerjaannya dapat mengukur secara psikologis individu tersebut terhadap pekerjaannya dan kinerjanya untuk mencapai penghargaan diri (Robbins \& Judge, 1998/2008). Safaria (2004) menyatakan bahwa pemberdayaan memberikan keyakinan kepada individu tentang kompetensi yang dimilikinya yang dapat meningkatkan harga diri dan kepuasan kerja, dan meningkatkan komitmen individu untuk berkontribusi terhadap organisasinya.

Pemberdayaan menurut Whetten dan Cameron (2005) adalah memampukan individu untuk dapat menumbuhkan kepercayaan pada dirinya, membantu memulihkan ketidakberdayaan, sehingga individu memiliki semangat, dan motivasi intrinsik dalam melakukan setiap tindakan. Pemberdayaan psikologis memiliki lima dimensi kunci, menurut Whetten dan Cameron (2005), yaitu kemampuan diri, penentuan diri, pengendalian diri, makna, dan kepercayaan. Kemampuan diri memiliki kontribusi dalam perilaku praktik keperawatan profesional, dan untuk mempertahankan perilaku praktik keperawatan professional diperlukan adanya pemberdayaan (Manojlovich, 2007). Wibowo (2007) menyatakan bahwa kemampuan diri mencerminkan kompetensi yang dimiliki individu.

Kepuasan individu dapat ditunjukkan dengan aktif bekerja dan berkomitmen terhadap organisasinya. Komitmen terhadap organisasi dapat dicerminkan dari turn over (Spreitzer, 2007). Hasil survei awal peneliti di salah satu rumah sakit Jakarta didapatkan bahwa ketidakpuasan perawat pelaksana terhadap pekerjaannya sebesar $46,2 \%$. Tenaga nonprofessional dengan usia tengah baya cenderung memiliki ketidakpuasan dibandingkan dengan tenaga profesional (Robbins \& Judge, 1998/2008). Data lain yang didapatkan dari hasil survei peneliti pada salah satu rumah sakit adalah turn over perawat $14,49 \%$. Terjadinya turn over pada staf juga cenderung pada usia yang lebih muda dibandingkan dengan usia yang lebih tua. Hal ini disebabkan oleh penghasilan yang lebih tinggi (Robbins \& Judge, 1998/2008). Hasil wawancara didapatkan bahwa perawat pelaksana dalam melaksanakan tugas lebih berfokus terhadap tindakan medis daripada tindakan keperawatan.

Berdasarkan hal tersebut dapat dianalisis bahwa karakteristik perawat dapat memengaruhi pemberdayaan psikologis perawat untuk meningkatkan kinerja dan kepuasan kerja. Tujuan dari penelitian ini adalah untuk mengetahui karakteristik perawat dengan pemberdayaan psikologis perawat pelaksana.

\section{Metode}

Desain pada penelitian ini adalah deskripsi korelasi dengan cross-sectional. Sampel dalam penelitian ini adalah seratus lima belas perawat pelaksana, dengan teknik total sampling. Uji validitas pada kuesioner pemberdayaan psikologis dilakukan dengan ahlinya, sedangkan uji reliabilitas pada tiga puluh perawat dengan menggunakan Cronbach's alpha coeficient dan hasil uji adalah 09,02.

\section{Hasil}

Karakteristik perawat terdiri atas usia, jenis kelamin, tingkat pendidikan, status perkawinan, status pekerjaan, dan lama kerja.

Pada Tabel 1 menunjukkan bahwa sebagian besar perawat pelaksana yang berjenis kelamin perempuan 91,3\%, berpendidikan D-3 Keperawatan $88,7 \%$, mempunyai status kawin $51,3 \%$, dengan status pekerjaan non-PNS 79,1\%. Pada Tabel 2 dapat dilihat bahwa rata-rata usia perawat pelaksana adalah 27,9 tahun, dengan rata-rata lama kerja perawat pelaksana adalah 5,1 tahun.

Pada Tabel 3 menunjukkan bahwa sebagian besar $55,7 \%$ perawat pelaksana diberdayakan dengan baik secara psikologis, sedangkan 44,3\% perawat pelaksana kurang diberdayakan secara 
psikologis. Berdasarkan hasil penelitian yang berhubungan dengan pemberdayaan psikologis adalah jenis kelamin.

Pada Tabel 4 dinyatakan bahwa karakteristik jenis kelamin yang berhubungan dengan pemberdayaan psikologis dengan $\mathrm{p}=0,041$ dan $90 \%$ perawat pelaksana yang berjenis kelamin lakilaki diberdayakan dibanding perawat yang berjenis kelamin perempuan dan hasil pada OR didapatkan 3,844. Hal ini menunjukkan bahwa perawat pelaksana yang berjenis kelamin laki-laki

Tabel 1. Karakteristik Perawat Pelaksana menurut Jenis Kelamin, Tingkat Pendidikan Status Perkawinan, Status Pekerjaan

\begin{tabular}{|c|c|c|}
\hline Variabel & Frekuensi & Persentase (\%) \\
\hline $\begin{array}{l}\text { Jenis Kelamin } \\
\text { a. Laki-laki } \\
\text { b. Perempuan }\end{array}$ & $\begin{array}{r}10 \\
105\end{array}$ & $\begin{array}{c}8,7 \\
91,3\end{array}$ \\
\hline $\begin{array}{l}\text { Tingkat Pendidikan } \\
\text { a. Surat Perintah } \\
\text { Kerja (SPK) }\end{array}$ & 5 & 4,3 \\
\hline $\begin{array}{l}\text { b. D-3 Keperawatan } \\
\text { c. S-1 Keperawatan }\end{array}$ & $\begin{array}{c}102 \\
8\end{array}$ & $\begin{array}{c}88,7 \\
7,0\end{array}$ \\
\hline $\begin{array}{l}\text { Status Perkawinan } \\
\text { a. Kawin } \\
\text { b. Tidak Kawin }\end{array}$ & $\begin{array}{l}59 \\
56\end{array}$ & $\begin{array}{l}51,3 \\
48,7\end{array}$ \\
\hline $\begin{array}{l}\text { Status Pekerjaan } \\
\text { a. Non-Pegawai } \\
\text { Negeri Sipil (Non- } \\
\text { PNS) }\end{array}$ & 91 & 79,1 \\
\hline $\begin{array}{l}\text { b. Pegawai Tidak } \\
\text { Tetap (PTT) }\end{array}$ & 7 & 6,1 \\
\hline $\begin{array}{l}\text { c. Calon Pegawai } \\
\text { Negeri Sipil } \\
\text { (CPNS) }\end{array}$ & 6 & 5,2 \\
\hline $\begin{array}{l}\text { d. Pegawai Negeri } \\
\text { Sipil (PNS) }\end{array}$ & 11 & 9,6 \\
\hline
\end{tabular}

Tabel 2. Karakteristik Perawat Pelaksana Menurut Usia dan Lama Kerja

\begin{tabular}{lcccc}
\hline Variabel & $\begin{array}{c}\text { Mean } \\
\text { Median }\end{array}$ & SD & $\begin{array}{c}\text { Minimal- } \\
\text { Maksimal }\end{array}$ & $\begin{array}{c}\mathbf{9 5 \%} \\
\text { CI }\end{array}$ \\
\hline Usia & 27,9 & 4,3 & 21 & 27,2 \\
& 27,0 & & 41 & 28,7 \\
Lama kerja & 5,1 & 4,2 & 0,6 & 4,4 \\
& 4,0 & & 22 & 5,9 \\
\hline
\end{tabular}

Tabel 3. Pemberdayaan Psikologis Perawat Pelaksana

\begin{tabular}{lcc}
\hline Pemberdayaan & Frekuensi & Persentase \\
\hline Kurang & 51 & 44,3 \\
Baik & 64 & 55,7 \\
\hline
\end{tabular}

berpeluang 3,8 kali untuk diberdayakan dibanding perawat pelaksana yang berjenis kelamin perempuan $(95 \% \mathrm{CI}=1,001-66,893)$.

Namun, pada Tabel 4 tersebut dapat dilihat perbedaan masing-masing karakteristik untuk status pendidikan D-3 lebih diberdayakan secara psikologis dibanding status pendidikan SPK dan S-1 Keperawatan. Pada status pernikahan perawat yang tidak kawin lebih diberdayakan secara psikologis dibanding yang kawin. Pada status pekerjaan perawat yang Pegawai Negeri Sipil (PNS)/Calon Pegawai Negeri Sipil (CPNS) lebih diberdayakan dibandingkan status PTT dan Non-PNS.

\section{Pembahasan}

Hasil penelitian didapatkan bahwa karakteristik perawat yang berhubungan dengan pemberdayaan psikologis adalah jenis kelamin. Di rumah sakit tempat lokasi peneliti di salah satu rumah sakit di Jakarta didapatkan hampir keseluruhan perawat berjenis kelamin perempuan dan terkait dengan pemberdayaan didapatkan hasil bahwa perawat berjenis kelamin perempuan yang diberdayakan secara psikologis dengan yang tidak diberdayakan hampir tidak ada perbedaan. Sementara jumlah perawat yang berjenis kelamin laki-laki di lokasi penelitian tersebut didapatkan hampir keseluruhan diberdayakan secara psikologis. Analisis dari hasil tersebut bahwa terdapat perbedaan antara perawat berjenis kelamin perempuan dan laki-laki dalam pemberdayaan psikologis. Namun, hasil penelitian menurut Rogers, Chamberlin, Ellison, dan Crean (1997) menyatakan bahwa tidak ada perbedaan antara jenis kelamin laki-laki maupun perempuan dengan pemberdayaan. 
Hasil penelitian ini sejalan dengan dengan hasil penelitian menurut Sitiawati dan Zulkaida (2007) yang menyatakan ada perbedaan dalam komitmen staf, yaitu staf yang berjenis kelamin laki-laki memiliki komitmen yang tinggi dibanding staf perempuan. Spreitzer (2007) menyatakan bahwa kepuasan individu dapat ditunjukkan dengan aktif bekerja dan berkomitmen terhadap organisasinya, dan komitmen terhadap organisasi dapat dicerminkan melalui turn over. Selain itu, Spreitzer (2007) menyatakan juga bahwa tim yang memiliki pemberdayaan menunjukkan produktivitas dan kinerja yang tinggi, individu yang memiliki kinerja yang tinggi berarti memiliki kompetensi dan kemampuan untuk melaksanakan tugasnya, sehingga dapat memberikan kepuasan kepada pasien.

Robbins dan Judge (1998/2008) menyatakan bahwa ketidakhadiran pada perempuan lebih besar dibanding pada laki-laki dan hal tersebut pada umumnya dikarenakan masalah rumah tangga yang merupakan tanggung jawab pada perempuan seperti yang terjadi di Amerika Utara. Robbins dan Judge (1998/2008) juga menyatakan bahwa perempuan lebih memilih jadwal kerja paruh waktu dikarenakan lebih memilih untuk mengurus keluarganya.

Semakin lama individu berada dalam satu pekerjaan, maka lebih kecil kemungkinan untuk mengundurkan diri dari pekerjaan (Robbins dan Judge, 1998/2008). Semakin lama masa kerja perawat maka individu mampu menyesuaikan diri terhadap lingkungan pekerjaannya sehingga dapat mencapai kepuasan dalam menjalankan pekerjaannya (Aprizal, Kuntjoro, \& Probandari, 2008). Lama kerja perawat di salah satu rumah sakit Jakarta lama kerja perawat rata-rata lima tahun. Berdasarkan hasil survei penelitian di salah satu rumah sakit di Jakarta didapatkan turn over perawat $14,49 \%$, data tersebut merupakan

Tabel 4. Karakteristik Perawat pada Pemberdayaan Psikologis

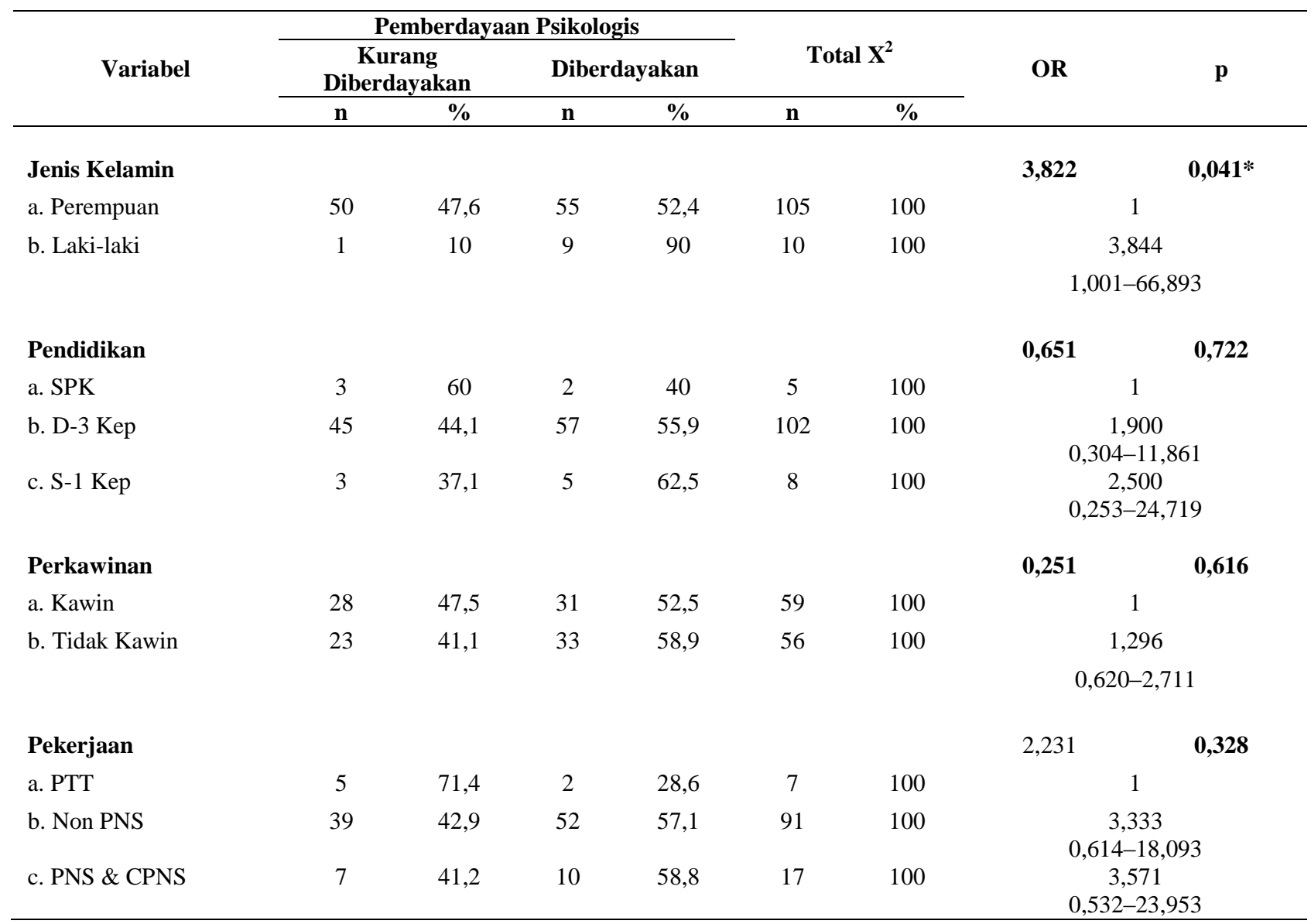

\footnotetext{
* Bermakna pada $\alpha<0,05$
} 
data yang perlu diwaspadai pada turn over perawat yang optimal adalah 5-10\% per tahun (Gauerke, 1977 dalam Gillies, 1994). Hal ini membuktikan bahwa perawat di rumah sakit masih perlu untuk diberdayakan secara psikologis.

Hasil survei peneliti di salah satu rumah sakit Jakarta menemukan bahwa terdapat hampir separuh dari jumlah perawat perempuan terjadi ketidakpuasan terhadap pekerjaannya. Sementara itu, hasil penelitian yang didapatkan, yaitu jumlah perawat yang berjenis kelamin perempuan yang tidak diberdayakan hampir tidak memiliki perbedaan dengan jumlah perawat yang mengalami ketidakpuasan dalam bekerja. Ini berarti ketidakpuasan perawat dapat terjadi terhadap perawat berjenis kelamin perempuan yang mencerminkan perawat mengalami ketidakberdayaan secara psikologis.

Berdasarkan uraian tersebut dapat dianalisis bahwa perawat yang berjenis kelamin perempuan yang diberdayakan mencerminkan perawat yang memiliki kinerja baik, sedangkan perawat yang berjenis kelamin perempuan yang tidak diberdayakan mencerminkan memiliki kinerja yang tidak baik. Namun, perawat yang berjenis kelamin laki-laki di salah satu rumah sakit Jakarta tersebut secara keseluruhan mencerminkan memiliki kinerja yang baik. Whetten dan Cameron (2009) menyatakan bahwa pemberdayaan psikologis merupakan kunci efektif dan dasar terbentuknya kinerja. Penelitian Santoso (2006) menunjukkan ada hubungan antara pemberdayaan perawat dengan kinerja perawat pelaksana.

Eagly dan Johannesen-Schmidt (2001) dalam penelitiannya menyatakan bahwa perempuan maupun laki-laki memiliki peran yang sama dalam organisasinya seperti memberikan normanorma yang mengatur kinerja, melakukan pengawasan kinerja staf, memberikan informasi. Pernyataan tersebut dapat dianalisis bahwa seharusnya tanggung jawab dalam meningkatkan organisasi merupakan tanggung jawab bersama, baik perempuan maupun laki-laki. Namun, adanya perbedaan terhadap hasil penelitian tersebut membuktikan bahwa perbedaan kontribusi karakteristik perawat memengaruhi pemberdayaan psikologis perawat itu sendiri dalam bekerja di rumah sakit.

Apabila perbedaan psikologis perawat ditinjau berdasarkan karakteristik status perkawinan, hal itu dapat diuraikan bahwa perawat yang diberdayakan di salah satu rumah sakit di Jakarta mayoritas adalah perawat yang belum menikah. Berbeda dengan hasil penelitian Gatot dan Adisasmito (2005) yang menyatakan bahwa perawat yang sudah menikah memiliki kepuasan dalam bekerja. Spreitzer (2007) menyatakan bahwa pemberdayaan memberikan dampak terhadap sikap kerja yang positif, dimana individu yang diberdayakan dapat memengaruhi tim kerjanya sehingga dapat mencapai kepuasan kerja. Demikian pula pernyataan Safaria (2004), bahwa pemberdayaan memberikan keyakinan kepada individu tentang kompetensi yang dimilikinya, yaitu dengan kompetensi dapat meningkatkan harga diri dan kepuasan kerja, dan meningkatkan komitmen individu untuk berkontribusi terhadap organisasinya. Hal ini dapat diartikan bahwa perawat yang berstatus menikah maupun yang tidak menikah memiliki kepuasan kerja dan mempunyai peluang untuk diberdayakan, selain itu perawat yang merasakan puas karena memiliki sikap positif dalam bekerja sama dengan tim, memiliki komitmen, dan kepuasan kerja.

\section{Kesimpulan}

Hasil penelitian berdasarkan uraian tersebut dapat disimpulkan bahwa jenis kelamin berhubungan dengan pemberdayaan psikologis dan ada perbedaan antara perawat yang berjenis kelamin perempuan dan perawat berjenis kelamin lakilaki. Perawat laki-laki memiliki pemberdayaan psikologis dan memiliki peluang untuk diberdayakan secara psikologis dibandingkan dengan perawat perempuan. Saran dari hasil penelitian ini adalah perlu dilakukan pemberdayaan psikologis terhadap perawat, baik yang berjenis kelamin laki-laki atau perempuan serta perlu mengusulkan pendidikan formal dan informal untuk perawat pelaksana khususnya yang memiliki lama kerja minimal lima tahun. Selain itu juga, kepala ruangan perlu memberi pengarahan untuk 
membina seluruh perawat melalui supervisi sehingga dapat memiliki kompetensi kinerja yang baik, dan mencerminkan pemberdayaan psikologis perawat (MS, RR, PN).

\section{Referensi}

Aditama, T.Y. (2008). Manajemen adminstrasi rumah sakit (Edisi Kedua). Jakarta: Penerbit Universitas Indonesia.

Aprizal, S., Kuntjoro, T., \& Probandari, A. (2008). Kepuasan kerja perawat di Rumah Sakit Jiwa Prof. HB. Sa'anin Padang. Diperoleh dari http://www. lrckmpk.ugm.ac.id/id/UPPDF/_working/N o.17_Yana_04_08.pdf.

Eagly, A.H., \& Johannesen-Schmidt, M.C. (2001). The Leadership styles of women and men. Journal of Social Issues, 1 (12), 1-31.

Gillies, D.A. (1994). Nursing management: A system approach (3rd Ed.). Philadelphia: W.B. Saunders Company.

Gatot, D.B., \& Adisasmito, W. (2005). Hubungan karakteristik perawat, isi pekerjaan terhadap kepuasan kerja perawat di Instalasi Rawat Inap RSUD Gunung Jati Cirebon. Jurnal Kesehatan Makara, 9 (1), $1-8$.

Huber, D.L (2006). Leadership and nursing care management (3rd Ed.). Philadelphia: Saunders Elsevier.

Manojlovich, M. (2007). Power and empowerment in nursing: Looking backward to inform the future. The Online Journal of Issues in Nursing. A Scholarly Journal of the American Nurses Association, 12 (1), 1-16.

Robbins, S.P., \& Judge, T.A. (2008). Perilaku organisasi. Edisi kedua belas. Buku 1. (Angelica, D., penerjemah). Jakarta: Penerbit Salemba Empat.
Robbins, S.P., \& Judge, T.A. (2008). Perilaku organisasi. Ed ke 12. Buku 1. (Angelica, D., Cahyani., R., \& Rosyid, A., penerjemah). Buku asli diterbitkan tahun 1998. New Jersey: Pearson Education.

Rogers, E.S., Chamberlin, J., Ellison, M.L., \& Crean, T. (1997). A Consumer-constructed scale to measure empowerment among users of mental health services. Psychiatric Services, 48 (8), 1042-1047.

Safaria, T. (2004). Kepemimpinan. (Edisi Pertama). Yogyakarta: Penerbit Graha Ilmu.

Santoso, A. (2006). Hubungan empowerment dengan kinerja perawat pelaksana di rumah sakit umum kota Semarang (Tesis magister tidak dipublikasikan). Fakultas Ilmu Keperawatan Universitas Indonesia, Depok-Jawa Barat.

Sitiawati, D., \& Zulkaida, A. (2007). Perbedaan komitmen kerja berdasarkan orientasi peran gender pada karyawan di bidang kerja non tradisional. ISSN (2), 18582599. Diperoleh dari http://www. gunadarma.ac.id/library/articles/graduate/p sychology/2007/artikel_10502058.pdf.

Spreitzer, G. (2007). Taking stock: A review of more than twenty years of research on empowerment at work. For publication in the handbook of organizational behavior, Sage Publications. Diperoleh dari http://webuser.bus.

umich.edu/spreitze/EmpowermentandSelfmanagement.pdf.

Whetten, D.A., \& Cameron, K.S. (2005). Developing management skills (6th ed). International Edition. New Jersey: Pearson Prentice Hall.

Wibowo. (2007). Mananjemen kinerja. (Edisi Pertama). Jakarta: PT Raja Gravindo. 